\begin{tabular}{|c|c|}
\hline & Literature Reviews \\
MAGNA & Berkala Ilmiah Kedokteran dan Kesehatan \\
MEDIKA & Journal Page: https://jurnal.unimus.ac.id/index.php/APKKM \\
\cline { 2 - 2 } &
\end{tabular}

\title{
Isolation and Characterization of Wound Healing Compounds from Chloroform Extract of Binahong Leaves (Anredera cordifolia (Ten.) Steenis)
}

Siti Rohani ${ }^{1}$, Mitayani Purwoko ${ }^{2}$

12)Medical Faculty, University Muhammadiyah of Palembang

\begin{tabular}{l}
\hline \multicolumn{1}{c}{ Article Info } \\
\hline Article history: \\
Received 23 Nopember 2020 \\
Revised 22 December 2020 \\
Accepted 22 December 2020 \\
Available online 1 February 2021 \\
\hline Keywords: \\
Anredera cordifolia (Ten) Steenis, \\
Spectroscopy, UV, FTIR, GCMS \\
\hline Correspondence: \\
sitirohanipandiangan@gmail.com \\
\hline
\end{tabular}

How to cite this article:

1. Rohani S., Purwoko M. Isolation and Characterization of Wound Healing Compounds from Chloroform Extract of Binahong Leaves (Anredera cordifolia (Ten.) Steenis). MAGNA MEDIKA Berk Ilm Kedokt dan Kesehat. 2021;8(1):35-54

\begin{tabular}{l} 
Abstract \\
\hline The leaves of Binahong (Anredera cordifolia (Ten) Steenis) have been \\
widely studied to have benefits and uses in various medical purposes, one \\
of which is in the wound healing process. The existence of several active \\
compounds contained in the leaves of the Binahong tree plant have an \\
important role in wound healing, such as flavonoids, terpenoids, \\
alkaloids, saponins, ascorbic acid and citrate compounds, these \\
compounds are the targeted for further process of this natural product. \\
The eminence of the extraction method that is used repeatedly and \\
consistently to obtain pure compounds from Binahong leaves to be \\
isolated is the one of topics discussed in this literature study. The \\
perspective of implementation from liquid-solid extraction followed by \\
liquid-liquid extraction using chloroform as a solvent is discussed \\
comprehensively in this article. The identification of the isolation of \\
compounds are able to conducted by implemented a thin layer \\
chromatography (TLC) techniques, and for the further structural \\
determination by UV, MS, FTIR, NMR spectroscopy and separation \\
techniques using GC-MS. Respectively, the components are successfully \\
to be identified and reported in previous research, for the following \\
criteria that have been completed, some isolated active compound are \\
purposed as the candidate for the wound healing agent. For the further \\
application it is reasonable to implied these matters for some \\
pharmaceutical products.
\end{tabular}

2021 MAGNA MEDIKA: Berkala Ilmiah Kedokteran dan Kesehatan with CC BY NC SA license 


\section{PENDAHULUAN}

Potensi kekayaan alam bangsa Indonesia salah satunya berasal dari sumber daya hayati atau biodiversitas di setiap daerah yang khas dan tidak dapat ditemui di tempat lain. Tumbuhan yang dapat ditemui di alam bebas di hutan tropis Indonesia banyak dilaporkan mengandung senyawa aktif seperti antioksidan, antitoksik, bahan penyembuh luka, dan aktivitas lainnya. ${ }^{1,2}$ Dalam beberapa dekade ini, penelitian mengenai pengembangan proses isolasi senyawa penyembuh luka mulai marak dikembangkan. ${ }^{3}$ Salah satu tumbuhan khas yang terdapat di hutan tropis Indonesia adalah hasil ekstraksi daun Binahong atau yang memiliki nama latin (Anredera cordifolia (Ten) Steenis). ${ }^{4}$ Luka mengakibatkan kerusakan pada struktur jaringan dan berkelanjutan dengan keadaan perdarahan. ${ }^{5}$ Banyak tanaman obat yang dapat digunakan untuk memperpendek penyembuhan luka khususnya dalam kasus diabetes, salah satunya adalah daun binahong (Anredera cordifolia (Ten.) Steenis). ${ }^{2,6}$ Kandungan kimia daun binahong pada penelitian sebelumya telah dilaporkan bahwa terdapat kandungan saponin, alkaloid, terpenoid dan flavonoid. ${ }^{7}$ Senyawa-senyawa kimia daun binahong diduga dapat membantu proses penyembuhan luka yaitu asam askorbat, saponin alkaloid dan flavonoid. ${ }^{7}$ Saponin berfungsi sebagai pembersih dan antiseptik untuk mencegah pertumbuhan mikro-organisme yang terjadi pada luka sehingga luka tidak mengalami infeksi berat dan merangsang pembentukan kolagen I, yaitu protein yang berperan dalam luka penyembuhan. ${ }^{8}$

Alkaloid memiliki kemampuan sebagai antibakteri dengan mengganggu komponen penyusun sel bakteri (peptidoglikan), sehingga lapisan dinding sel tidak sepenuhnya terbentuk dan menyebabkan kematian sel-sel ini. ${ }^{9,10}$ Asam askorbat dalam binahong memiliki fungsi sebagai antioksidan mengaktifkan enzim prolil hidroksilase yang mendukung pembentukan kolagen dalam penyembuhan luka. ${ }^{11,12}$ Keterlibatan senyawa asam juga berperan penting dalam proses penyembuhan luka, beberapa penelitian sebelumnya melaporkan bahwa asam sitrat dapat menurunkan aktivitas mikroba pada luka. Pengendalian nilai $\mathrm{pH}$ adalah penting dalam proses penyembuhan luka. Asam sitrat memiliki peran dalam penyembuhan luka, mekanisme kerja asam sitrat dalam penyembuhan luka yakni melalui proses penurunan $\mathrm{pH}$ dari area luka, kemudian menghambat kerja dari bakteri, meningkatkan nilai konsentrasi oksigen dan mampu mempercepat migrasi serta proliferasi fibroblast. ${ }^{13,14}$ Berdasarkan hal tersebut dan guna melengkapi data, maka penulis tertarik melakukan studi literatur mengenai isolasi dan mengkarakterisasi senyawa penyembuh luka dari daun binahong.

Dari berbagai macam kandungan senyawa yang dapat berperan sebagai agen senyawa aktif penyembuh luka, proses ekstraksi senyawa aktif tersebut menjadi suatu proses yang krusial dalam mengambil senyawa yang terkandung pada bagian tertentu dari sebuah tumbuhan. Kesalahan proses 
ekstraski dapat menyebabkan dekomposisi senyawa, proses ekstraksi yang tidak optimal, dan mengubah struktur dasar dari senyawa target. Beberapa metode ekstraksi serta isolasi senyawa telah banyak diaplikasikan, ekstraski padat cair melalui proses maserasi, refluks dan distilasi menjadi salah satu teknik unggulan yang umum digunakan dalam proses ekstraski senyawa aktif pada bagian tumbuhan obat. ${ }^{15,16}$ Pada artikel ilmiah ini akan dibahas mengenai hasil penelusuran pustaka dari penelitian terdahulu, yang membahas metode ekstraksi senyawa aktif daun binahong yang dapat dimanfaatkan sebagai bahan aktif dalam proses penyembuhan luka. Identifikasi senyawa juga akan dibahas menggunakan metode spektroskopi UV, FTIR dan GC-MS.

Dari artikel ini diharapkan dapat menjadi suatu kontribusi akademik sebagai bahan informasi di bidang kedokteran khususnya farmakologi, biologi molekuler, kimia medis dan ilmu terkait kedokteran kesehatan sehingga daun binahong berpeluang dikembangkan sebagai fitofarmaka untuk pengobatan luka. Secara klinis dapat menambah wawasan dan informasi bagi klinisi dalam membantu proses penyembuhan luka dengan memanfaatkan kandungan daun binahong. Secara sosial dapat menjadi sumber informasi masyarakat dalam membantu proses penyembuhan luka dengan menggunakan bahan alami daun binahong yang mudah didapat masyarakat dengan harga terjangkau.

\section{EKTRAKSI SENYAWA AKTIF: Teknik}

\section{Padat Cair pada Tumbuhan Hasil Alam}

Teknik ekstraksi senyawa aktif yang terdapat ditumbuhan hasil alam mejadi salah satu hal yang menentukan senyawa hasil yang akan diperoleh dari sebuah sampel. Tantangan yang dihadapi dalam proses ekstraksi senyawa aktif pada sampel tumbuhan hasil alam adalah menghindari proses dekomposisi atau penguraian yang terjadi selama ekstraksi berlangsung. Dalam beberapa hal senyawa aktif yang tergolong sebagai senyawa hidrokarbon organik yang sensitive terhadap perlakuan termal dan radiasi gelombang elektromagnetik menjadikan pemilihan teknik ekstraksi dan isolasi menjadi penting untuk menghindari penguraian senyawa aktif yang ditargetkan. ${ }^{15,16}$

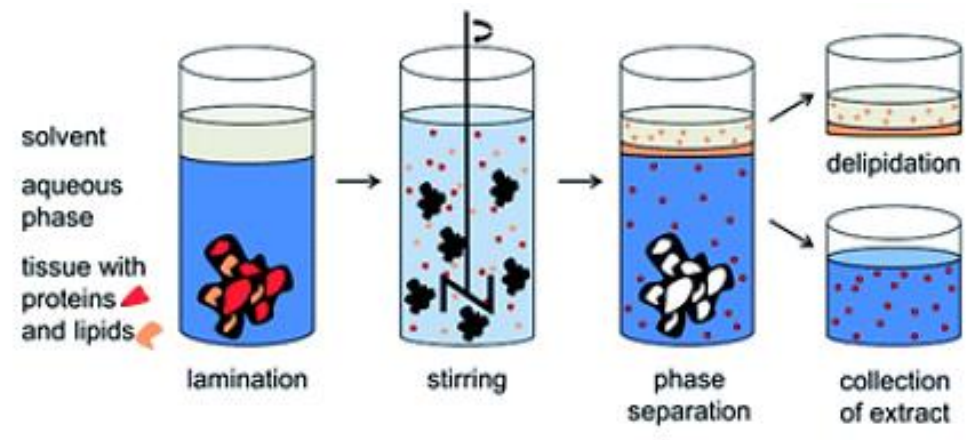

Gambar 1. Metode Ekstraksi Padat-Cair. ${ }^{17}$ 
Metode ekstraksi padat cair yang diawali pada proses pembuatan simplisia dengan membuat potongan kecil sampel yang kemudian direndam dalam pelarut organik yang sesuai, dalam beberapa kasus tertentu senyawa target yang telah diidentifikasi terlebih dahulu telah memiliki referensi pelarut yang baik digunakan untuk mendistribusikan senyawa dari fasa padat ke fasa cair. Perbedaan kepolaran merupakan suatu parameter penting, azas like dissolved like atau senyawa polar melarutkan senyawa polar dan senyawa non-polar melarutkan senyawa nonpolar menjadi suatu konsep dasar dalam mempertimbangkan pelarut pada proses ekstraksi. 15,16,18 Kemudian proses selanjutnya penyaringan untuk memisahkan residu hasil proses perendaman menggunakan pelarut yang dipakai. Filtrat hasil filtrasi kemudian didistilasi menggunakan rotary evaporator untuk menghilangkan pelarut dan hasil ekstraksi akan menghasilkan suatu senyawa konsentrat yang tercampur yang belum murni. Ekstraksi bertingkat melalui proses ekstraksi cair-cair dengan corong pisah, perendaman menggunakan solven, dan kromatografi cair-cair. ${ }^{16,19}$

\section{TEKNIK IDENTIFIKASI SENYAWA HASIL ISOLASI}

\section{Kromatografi Lapis Tipis}

Setelah dilakukan ekstraksi, dilakukan identifikasi produk menggunakan metode paling sederhana yakni kromatografi lapis tipis. Metode ini dapat digunakan untuk menunjukkan komposisi jumlah senyawa yang diperoleh dari proses isolasi senyawa aktif yang dilakukan. Pengamatan umumnya dilakuakan secara visual pada rentang panjang gelombang cahaya tampak atau pun di bawah penyinaran sinar pada nilai panjang gelombang Ultraviolet (UV) dengan mengamati fenomena perpendaran atau photoluminescence.

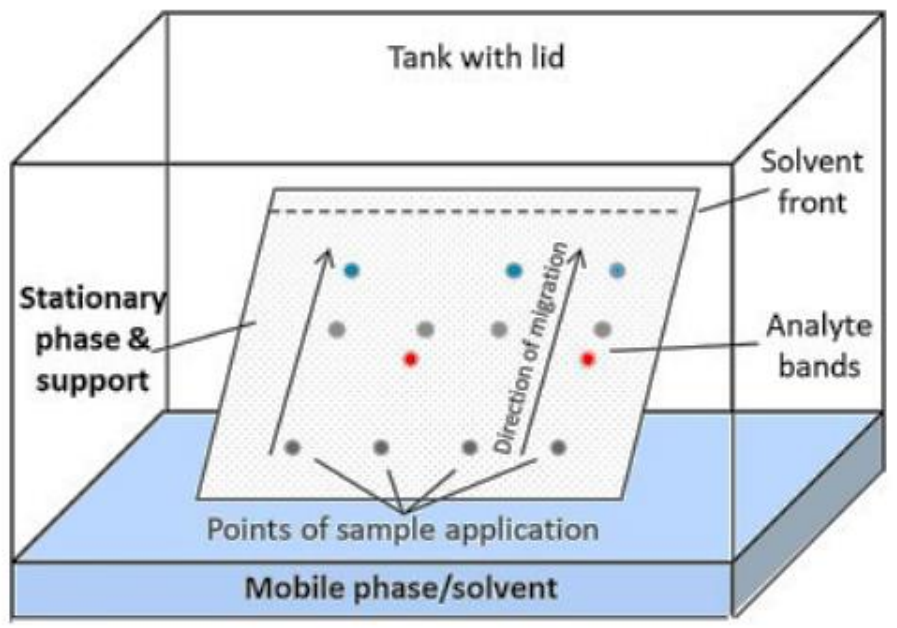

Gambar 2. Teknik Kromatografi Lapis Tipis. ${ }^{24}$

Kelompok senyawa yang memiliki gugus dengan cahaya radiasi elektromagnetik melalui kromofor atau gugus yang mampu berinteraksi proses adsorpsi radiasi, dapat diidentifikasi dengan 
menggunakan fenomena ini. Karakteristik gugus kromofor adalah umum dijumpai dalam jenis senyawa hidrokarbon organik seperti flavonoid, saponin, alkaloid, dan terpenoid. Sehingga teknik ini dapat dikategorikan sebagai metode identifikasi yang telah baku atau well established sebagai tahap identifikasi awal kemurnian suatu senyawa pada campuran hasil isolasi. ${ }^{20-23}$

\section{Teknik Karakterisasi FTIR}

Proses identifikasi senyawa yang perlu dilakukan setelah memperoleh senyawa murni ialah proses penentuan struktur kimia dari senyawa murni hasil isolasi. Teknik identifikasi struktur yang paling mendasar yang umum dilakukan dan dilaporkan pada publikasi adalah dengan mengaplikasikan teknik spektroskopi Inframerah (IR). Perkembangan metode dan instrumentasi analitik hingga saat ini salah satunya ditunjukkan dengan ditemukannya instrumen FTIR (Fourier Transformation Infra-Red). Instrumen FTIR digunakan untuk proses penentuan gugus fungsi yang mungkin terdapat pada struktur senyawa hasil isolasi. Molekul yang diiradiasi menggunakan sinar inframerah akan menyebabkan fenomena vibrasi molekuler dan memiliki tingkat energi vibrasi yang identik bagi setiap gugus fungsi. Hasil karaktersiasi spektroskopi FTIR akan menghasilkan suatu spectra dengan puncak dibilangan gelombang yang spesifik. ${ }^{25,26}$

Absorpsi molekul pada infrared atau inframerah terjadi ketika molekul tereksitasi ke tingkat energi yang lebih tinggi. Suatu molekul hanya menyerap frekuensi (energi) tertentu dari radiasi inframerah. Kegunaan spektroskopi IR adalah sebagai sidik jari suatu molekul dan untuk menentukan informasi struktural dari suatu molekul. Absorpsi dari tiap tipe ikatan $(\mathrm{N}-\mathrm{H}, \mathrm{C}-\mathrm{H}, \mathrm{O}-\mathrm{H}, \mathrm{C}-\mathrm{X}, \mathrm{C}=\mathrm{O}$, $\mathrm{C}-\mathrm{O}, \mathrm{C}-\mathrm{C}, \mathrm{C}=\mathrm{C}$, dan sebagainya) umumnya ditemukan hanya dalam porsi yang sedikit dari area vibrasi inframerah. Rentang kecil dari absorpsi dapat didefinisikan untuk tiap ikatan. Instrumen yang menentukan spektrum absorpsi dari suatu senyawa disebut spektrometer inframerah. Ada dua tipe spektrometer inframerah yang umum digunakan di laboratorium organik, yakni instrumen dispersif dan Fourier Transform (FT). Kedua tipe instrumen tersebut menyediakan spektrum senyawa dalam area umum 4000 hingga 400 cm-1. Meskipun kedunya menyediakan spektrum yang nyaris identik dari senyawa yang diuji, FT Infrared (FTIR) memberikan spektrum IR yang lebih cepat dari instrumen dispersive. Untuk menentukan spektrum IR dari suatu senyawa, senyawa harus di tempatkan di sampel holder atau sel. Sel harus terbuat dari bahan ionik seperti natrium klorida atau kalium bromida. Plat kalium bromida $(\mathrm{KBr})$ lebih mahal dan memiliki kelebihan dalam penggunaan di rentang 4000 hingga $400 \mathrm{~cm}^{-1}$. Natrium klorida luas digunakan karena murah, penggunaannya dalam rentang 4000 hingga 650 $\mathrm{cm}^{-1} \cdot 26,28$ 


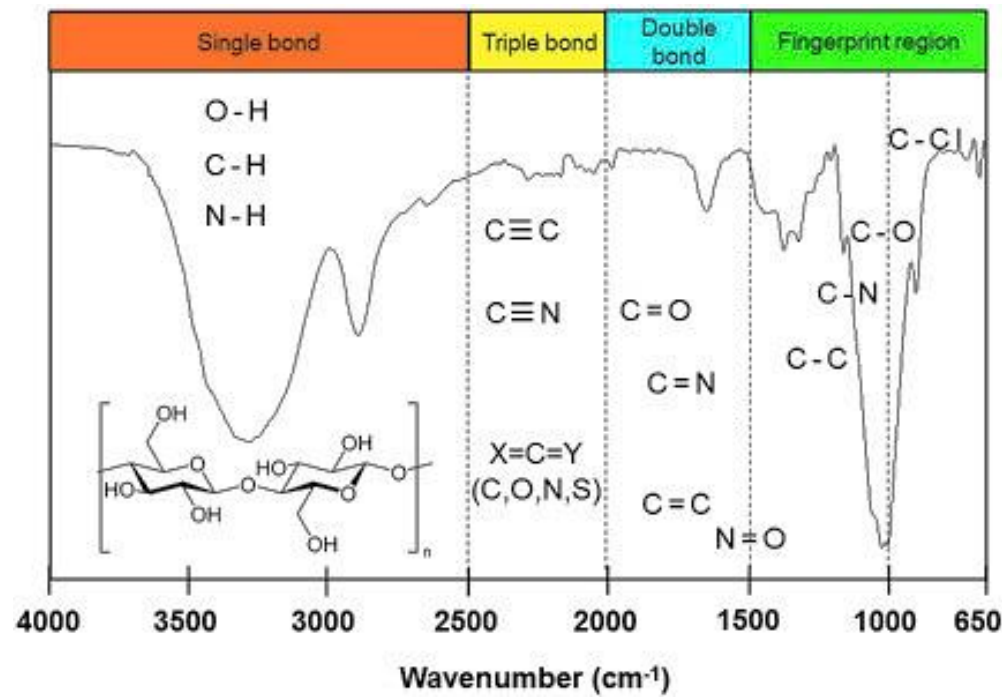

Gambar 3. Interpretasi Data FTIR. ${ }^{27}$

\section{Teknik Karakterisasi menggunakan GC-MS}

Teknik identifikasi senyawa yang selanjutnya yang sering diaplikasikan dalam penentuan komposisi senyawa pada suatu campuran hasil isolasi adalah Gas Chromatography-Mass Spectrometry (GC-MS). Pada teknik identifikasi ini, merupakan gabungan dari metode pemisahan menggunakan kromatografi gas, dan senyawa yang dipisahkan kemudian selanjutnya diidentifikasi menggunakan instrumen spektrometri massa. Hasil identifikasi senyawa menggunakan GC-MS akan menghasilkan suatu data grafik yang menunjukan hubungan kelimpahan dari suatu senyawa kimia berdasarkan perbedaan sifat dari senyawa dengan fasa diam yang berada pada kolom kromatografi. Senyawa yang dipisahkan memiliki karakteristik sebagai senyawa volatil yang dibawa menggunakan fasa gerak berupa gas yang tidak bereaksi dengan analit atau bersifat inert. Ketika senyawa hasil isolasi diinjeksikan pada suatu kolom kromatografi gas, akan terjadi fenomena pemisahan akibat perbedaan sifat dari senyawa hasil isolasi dengan kepolaran kolom kromatografi. Senyawa yang memiliki sifat kepolaran yang identik dengan kolom kromatografi akan tertahan pada kolom dan senyawa yang memiliki sifat tidak identikdengan kolom kromatografi akan keluar terlebih dahulu bersama fasa gerak yang berupa gas inert dan menuju detektor, dengan jenis detektor yang digunakan dapat berupa detektor ionisasi nyala atau flame ionization detektor (FID), detektor sinar ultraviolet (UV), dan detektor konduktivitas termal atau thermal conductivity detektor (TCD). Setelah proses pemisahan campuran berlangsung, senyawa yang berhasil dipisahkan akan diidentifikasi selanjutnya menggunakan spektrometri massa (MS), instrumentasi ini memiliki prinsip kerja identifikasi massa relative suatu senyawa dengan menseleksi partikel bermuatan menggunakan medan magnet. Senyawa hasil isolasi yang berhasil dipisahkan diberikan sejumlah berkas elektron berenergi tinggi. Kemudian senyawa hasil isolasi mengalami 
proses ionisasi, yang kemudian menyebabkan senyawa tersebut terpecah menjadi suatu fragmen-fragmen kecil dari molekul. Hasil ionisasi berupa fragmen akan diteruskan ke dalam suatu medan magnet yang kemudian akan dipisahkan dalam suatu fenomena seleksi bobot dari setiap fragmen bermuatan terhadap perbedaan medan magnet. Fragmen dari senyawa yang terpecah dari hasil pemisahan pada kromatografi gas yang telah diseleksi menggunakan medan magnet kemudian diteruskan ke detektor massa dan respon terukur sebagai sinyal elektrik yang diproses kemudian dan dikonversi menjadi massa dari setiap fragmenfargmen tersebut. Data akan direpresentasikan sebagai spektra massa dengan hubungan massa fragmen per muatan dengan intensitas relative terhadap kelimpahan fragmen. Kesesuaian data spektra massa akan dibandingkan dengan gudang data yang dimiliki setiap perusahaan instrumentasi dan standard senyawa yang dapat diperoleh di (National Institute of Standards and Technology) NIST. ${ }^{30,31}$

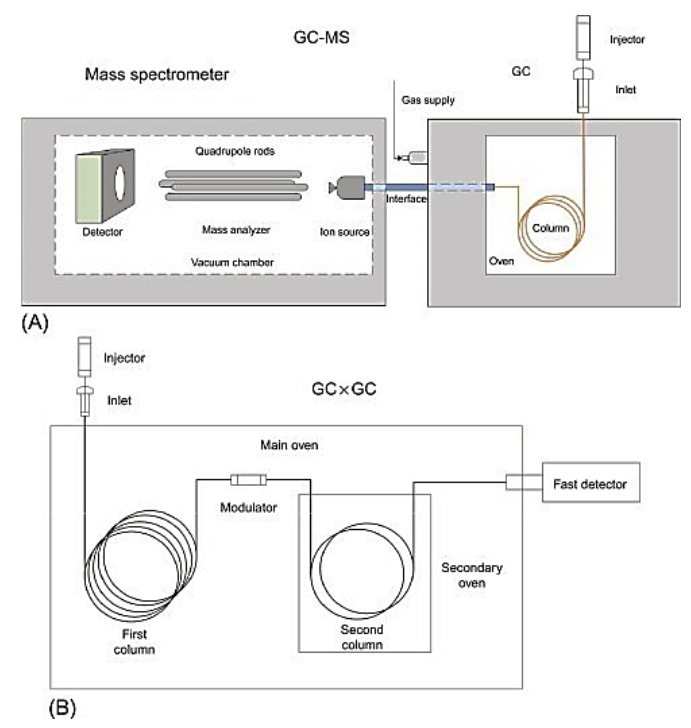

Gambar 4. Skematik Prinsip Kerja GC-MS. ${ }^{29}$

\section{Spektroskopi Nuclear Magnetic Resonance (NMR)}

Nuclear Magnetic Resonance (NMR) merupakan metode spektroskopi yang lebih penting dalam kimia organik dibandingkan spektroskopi inframerah. Banyak inti dapat dipelajari dengan teknik NMR, namun hydrogen dan karbon yang paling banyak tersedia. NMR memberikan informasi tentang jumlah atom magnetik yang jelas. Ketika atom hidrogen (proton) dipelajari, seseorang dapat menentukan jumlah dari tiap tipe yang jelas dari inti hidrogen. Informasi yang sama juga dapat ditentukan untuk inti karbon. Kombinasi data NMR dan spektroskopi inframerah sering digunakan untuk menentukan struktur molekul yang belum diketahui. ${ }^{28}$ Dalam spektroskopi NMR, karakteristik absorpsi energi oleh perputaran inti dalam medan magnet yang 
kuat, ketika diiradiasi oleh medan yang lebih lemah dan singkat, memungkinkan identifikasi atom dalam molekul. Absorpsi terjadi ketika inti tersebut bertransisi dari satu garis sejajar dalam medan ke garis sejajar lain. Prinsip dasar spektroskopi NMR yakni inti dari setiap isotop tertentu memiliki gerakan berputar di sekeliling sumbunya. Perputaran partikel berenergi atau sirkulasinya, menimbulkan kejadian magnetis sepanjang sumbu perputaran. Jika inti diletakkan di luar medan magnet maka momen magnetisnya dapat sejajar atau melawan medan magnet. ${ }^{32-34}$

Instrumen NMR terdiri dari magnet untuk memisahkan ketetapan energi perputaran inti, sedikitnya dua $\mathrm{rf}$ channels dimana satu untuk medan atau stabilisasi frekuensi dan satu untuk melengkapi energi iradiasi rf, sampel probe yang mengandung kumparan untuk coupling sampel dengan medan rf, detektor untuk memproses sinyal NMR, generator sapuan untuk menyapu baik medan magnet maupun medan rf 23 melalui frekuensi resonansi sampel, detektor, serta perekam untuk menampilkan spektrum. Pada spektroskopi NMR untuk mendeteksi proton, sampel dilarutkan di pelarut yang protonnya diganti atom deutrium, misalnya kloroform-d $(\mathrm{CDCl} 3)$, aseton- $\mathrm{d} 6$, dan benzena- $\mathrm{d} 6{ }^{34}$

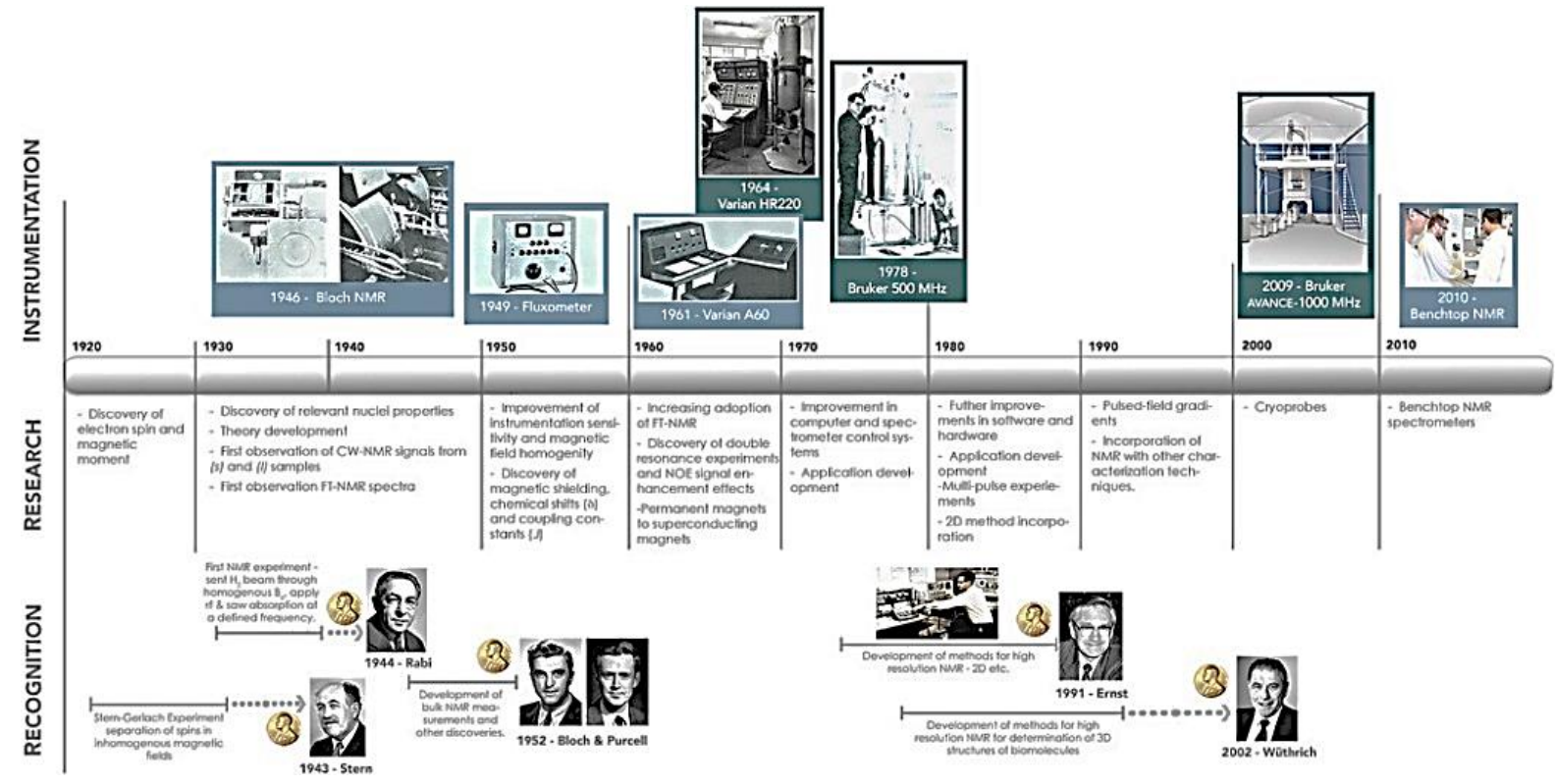

Gambar 5. Sejarah Pengembangan NMR. ${ }^{35}$ 


\section{PENYEMBUHAN LUKA}

Rangsang endogen dan eksogen dapat menimbulkan kerusakan sel, dan tahap selanjutnya akan memicu reaksi vaskuler kompleks pada jaringan yang mengandung pembuluh darah. Reaksi inflamasi berguna sebagai proteksi jaringan yang mengalami kerusakan agar tidak mengalami infeksi yang meluas tanpa terkendali. Proses inflamasi sangat erat hubungannya dengan penyembuhan luka. Tanpa adanya proses inflamasi proses penyembuhan luka tidak akan terjadi. Luka akan menyebabkan disrupsi vaskuler jaringan sekitar luka sehingga akan menyebabkan hipoksia jaringan luka pada tahap awal. ${ }^{36,37}$ Peradangan dan perbaikan merupakan proses yang terus menerus pada peyembuhan luka, sel - sel inflamasi, epitel, endotel, trombosit dan fibroblast keluar secara bersamaan dari tempatnya semula dan berinteraksi untuk mengembalikan kerusakan jaringan serta proses revaskularisasi. Kerusakan jaringan dan pembuluh darah akan diikuti oleh reaksi kompleks dalam jaringan pengikat yang memiliki pembuluh darah. Segera setelah trauma, luka akan mengalami kondisi lingkungan yang kekurangan oksigen. Hal ini tidak hanya disebabkan oleh kerusakan vaskuler, akan tetapi karena kebutuhan oksigen yang meningkat akibat proses katabolisme. Hipoksia jaringan akan menyebabkan tekanan oksigen jaringan rendah, pada tingkat seluler dan molekuler terbukti kondisi tersebut merupakan stimulator sinyal awal pada penyembuhan luka (tissue repair/angiogenesis), proliferasi fibroblast, sintesis faktor pertumbuhan.

Sel endotel yang mengalami hipoksia memproduksi sejumlah platelet-derived growth factor, endotelin, dan vascular endothelial growth factor yang berperan dalam proses angiogenesis, motilitas keratinosit juga akan meningkat dengan kondisi tekanan oksigen yang rendah..$^{38,39}$

\section{Peranan Oksigen dalam Penyembuhan Luka}

Pada tingkat seluler oksigen merupakan nutrisi yang penting bagi metabolism sel, terutama produksi energi. Energi tersebut terutama diperoleh dari Co- enzim ATP, yang merupakan energi kimia paling penting pada level molekul dan enzim ATP disintesis dalam mitokondria melalui proses fosforilasi oksidatif. Reaksi tersebut sangat tergantung pada oksigen dan tidak dapat berlangsung tanpa keberadaan oksigen. NADPHlinked oxygenase merupakan enzim yang bertanggung jawab dalam proses fagositosis leukosit. Pada fase inflamasi NADPH-linked oxygenase memproduksi sejumlah besar oksidan melalui konsumsi sejumlah besar oksigen. Penyembuhan luka dapat terjadi dengan keberadaan enzim tersebut, karena oksidan dibutuhkan untuk mencegah infeksi. Penelitian terkini menunjukkan hampir semua sel di lingkungan sekitar luka berkaitan erat dengan enzim-enzim tertentu yang merubah $\mathrm{O}_{2}$ menjadi reactive oxygen species (ROS), radikal bebas dan $\mathrm{H}_{2} \mathrm{O}_{2}$. ROS berperan sebagai selular messenger dalam mengadakan beberapa proses penting yang menyokong penyembuhan luka. Dengan demikian $\mathrm{O}_{2}$ tidak saja berperan sebagai nutrisi 
bagi luka tapi juga berperan sebagai antibiotik.

Platelet-derived growth factor (PDGF), membutuhkan

ROS, pada saat kerjanya tingkat selular, dengan demikian terapi $\mathrm{O}_{2}$ berperan dalam penyembuhan luka. ${ }^{40}$

\section{Fase Penyembuhan Luka}

\section{Fase Inflamasi}

Proses penyembuhan terjadi sejak awal pada saat terjadi luka, fase inflamasi terjadi pada hari $0-5$.

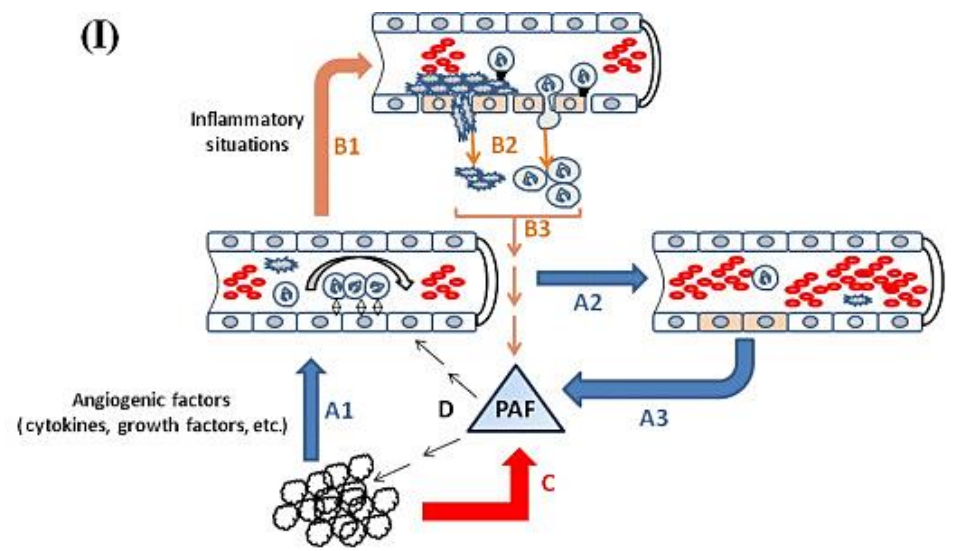

(II)

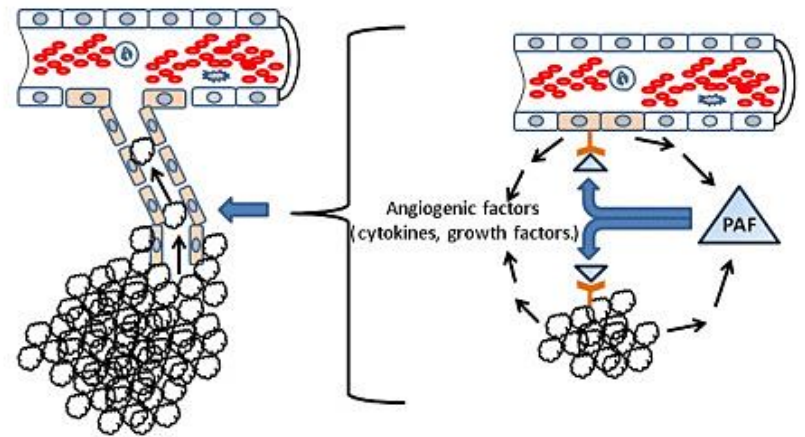

Endothelial cells Activated endothelial cells

(A) Leukocytes-PMNs

Cancer cells

(a) Redblood cells faktor Hageman. ${ }^{41}$

mengakibatkan kerusakan pada struktur jaringan dan mengakibatkan perdarahan. Pada tahap awal darah akan mengisi jaringan yang cedera dan terpaparnya darah terhadap kolagen berakibat terjadinya degranulasi trombosit dan pengaktifan

Gambar 6. Sistem Inflamasi Sel Kulit Manusia. ${ }^{41}$ 
Hal ini akan memicu sistem biologis lain seperti pengaktifan komplemen kinin, kaskade pembekuan dan pembentukan plasmin. Keadaan ini memperkuat sinyal dari tempat luka, sehingga tidak hanya mengaktifkan pembentukan bekuan yang menyatukan tepi luka akan tetapi juga akumulasi dari beberapa mitogen dan menarik zat kimia ke daerah luka. Pembentukan kinin dan prostaglandin menyebabkan vasodilatasi dan peningkatan permeabilitas pembuluh darah di daerah luka. Hal ini meyebabkan edema dan menimbulkan pembengkakan dan nyeri pada awal terjadinya luka. Leukosit PMN adalah sel pertama yang menuju ke tempat luka. Jumlahnya meningkat cepat dan mencapai puncaknya pada $24-48$ jam. Fungsi utamanya adalah melakukan fagositosis bakteri yang masuk. 40,41

\section{Fase Proliferasi}

Fase ini terjadi pada hari ke 3 - 14. Bila tidak ada kontaminasi atau infeksi yang bermakna, fase inflamasi akan berlangsung pendek. Jaringan granulasi merupakan kombinasi elemen seluler termasuk fibroblas dan sel inflamasi, bersamaan dengan timbulnya kapiler baru tertanam dalam jaringan longgar ekstraseluler matriks kolagen, fibronektin dan asam hialuronik. Fibroblas muncul pertama kali secara bermakna pada hari ke 3 dan mencapai puncaknya pada hari ke 7 . Meningkatnya jumlah fibroblas pada daerah luka merupakan kombinasi dari proses proliferasi dan migrasi. Fibroblas memproduksi kolagen dalam jumlah yang besar, kolagen ini berupa glikoprotein berantai tripel, unsur utama matriks luka ekstraseluler yang sangat berguna untuk membentuk kekuatan pada jaringan parut. Kolagen pertama kali terdeteksi pada hari ke 3 setelah luka, meningkat terus sampai minggu ke 3 . Pada awalnya penumpukan kolagen terjadi berlebihan kemudian fibril kolagen mengalami reorganisasi sehingga terbentuk jaringan reguler sepanjang luka. Fibroblas juga menyebabkan matriks fibronektin, asam hialuronik dan glikosaminoglikan. ${ }^{43,44}$ Proses revaskularisasi luka terjadi secara bersamaan dengan fibroplasia. Tunas - tunas kapiler tumbuh dari pembuluh darah yang berdekatan dengan luka, tunas-tunas kapiler ini bercabang di ujung.

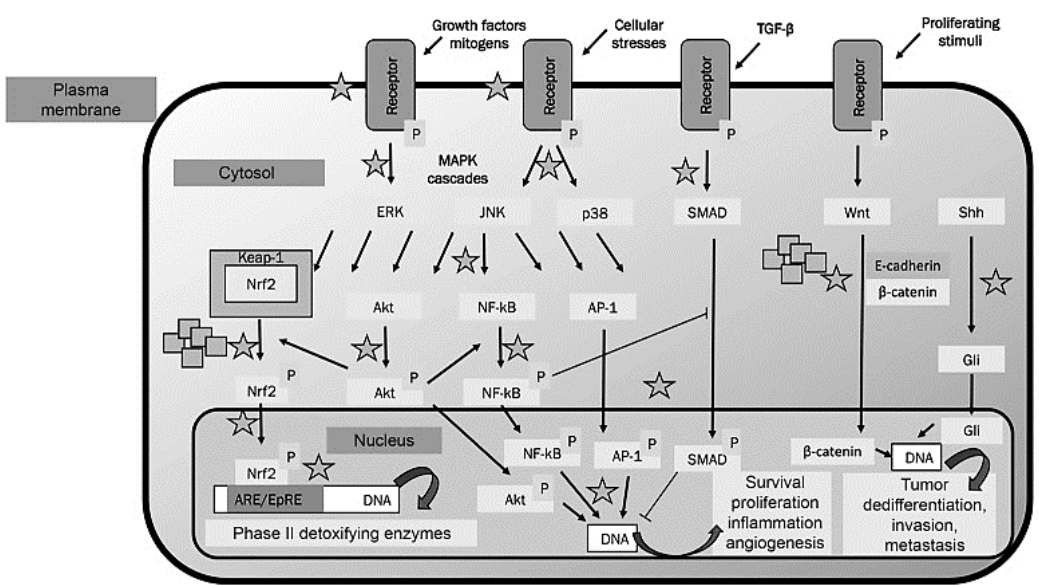

Gambar 7. Fase Proliferasi. ${ }^{42}$ 


\section{Fase Maturasi (Remodelling)}

Fase ini berlangsung dari hari ke-7 sampai dengan 1 tahun. Setelah matriks ekstrasel terbentuk, dimulailah reorganisasi. Matriks ekstrasel pada mulanya kaya akan fibronektin. Hal ini tidak hanya menghasilkan migrasi sel substratum dan pertumbuhan sel ke dalam tetapi juga menyebabkan penumpukan kolagen oleh fibroblas. Terbentuknya asam hialuronidase dan proteoglikan dengan berat molekul besar berperan pada pembentukan matriks ekstraseluler dengan konsistensi seperti gel dan membantu infiltrasi seluler. Kolagen selanjutnya berkembang cepat menjadi faktor utama yang membentuk matriks. Pada awalnya serabut kolagen terdistribusi secara acak membentuk persilangan dan beragregasi menjadi serabut fibril secara perlahan menyebabkan penyembuhan jaringan dan meningkatkan kekakuan serta kekuatan ketegangan luka. Setelah 5 hari periode jeda, pada saat ini bersesuaian dengan pembentukan jaringan granulasi awal dengan matriks sebagian besar tersusun dari fibronektin dan asam hialuronidase, selanjutnya akan terjadi peningkatan cepat dari kekuatan tahanan luka karena proses fibrogenesis kolagen. Pencapaian kekuatan tegangan luka berjalan lambat. Setelah 3 minggu kekuatan penyembuhan luka mencapai 20\% dari kekuatan akhir. ${ }^{44,45}$ Proses pengembalian ketegangan berjalan perlahan karena deposisi jaringan kolagen terus - menerus, remodeling serabut kolagen membentuk serabut-serabut kolagen lebih besar dan perubahan dari cross linking inter molekuler. Remodeling kolagen selama pembentukan jaringan parut tergantung proses sintesis dan katabolisme kolagen yang berkesinambungan. Degradasi kolagen pada luka dikendalikan oleh enzim kolagenase. Kecepatan sintesis kolagen yang tinggi mengembalikan luka ke jaringan normal dalam waktu 6 bulan sampai 1 tahun. ${ }^{40,44,46}$

\section{SENYAWA AKTIF: Kandungan Kimia dan}

\section{Manfaat Daun Binahong dalam}

\section{Penyembuhan Luka}

Binahong digunakan sebagai obat tradisional, termasuk penyembuhan luka bakar, luka setelah pasca melahirkan, dan lainnya. Daun binahong memiliki senyawa aktif sebagai antiinflamasi, antioksidan, antibakteri, dan sebagai analgesik. Efeknya disebabkan oleh beberapa komponen dalam binahong, seperti saponin, flavonoid, terpenoid, steroid dan alkaloid. ${ }^{47,48}$ Senyawasenyawa kimia daun binahong diduga dapat membantu proses penyembuhan luka yaitu asam askorbat, saponin, alkaloid dan flavonoid. ${ }^{49}$ Manfaat daun binahong berdasarkan survei tidak dapat dipisahkan dari senyawa aktif yang terkandung dalam daun binahong.

\section{Saponin}

Saponin adalah struktur aglikon ke dalam terpenoid dan steroid, struktur terpenoid merupakan satu unit isopren $\left(\mathrm{C}_{5} \mathrm{H} 8\right)$ atau gabungan lebih dari satu unit isopren, saponin berfungsi sebagai pembersih dan antiseptik untuk mencegah pertumbuhan mikroorganisme yang terjadi pada luka sehingga luka tidak mengalami infeksi berat dan mampu merangsang 
pembentukan kolagen I, yaitu protein yang berperan dalam luka penyembuhan. ${ }^{50,51}$ Alkaloid memiliki kemampuan sebagai antibakteri dengan mengganggu komponen penyusun sel bakteri (peptidoglikan), sehingga lapisan dinding sel tidak sepenuhnya terbentuk dan menyebabkan kematian sel-sel ini..$^{52,53}$

\section{Asam Askorbat}

Asam askorbat dalam binahong memiliki fungsi sebagai antioksidan mengaktifkan enzim prolil hidroksilase yang mendukung pembentukan kolagen dalam penyembuhan luka. ${ }^{54}$

\section{Flavonoid}

Beberapa senyawa flavonoid dapat menghambat pelepasan asam arakhidonat dan sekresi enzim lisosom dari membran dengan jalan memblok jalur siklooksigenase dan lipooksigenase secara langsung menyebabkan penghambatan biosintesis prostaglandin dan leukotrin, penghambatan akumulasi leukosit. ${ }^{55}$ Jenis flavonoid yang terkandung di dalam ekstrak binahong adalah flavonol. ${ }^{56}$ Dari hasil studi klinik dan eksperimen flavonoid dapat meningkatkan vaskularisasi dan menurunkan edema. Pada penelitian telah membuktikan bahwa flavonoid mempunyai efek antiinflamasi dan antioksidan. Kandungan flavonoid juga diyakini mempunyai manfaat dalam proses penyembuhan luka. ${ }^{57}$ Senyawa flavonoid seperti seperti hisperidin, apigenin, luteonin, kaemferol dan kuarsetin memiliki efek antiinflamasi. $^{58}$ Telah disebutkan juga bahwa flavonoid, yaitu kuersetin, apigenin dan luteonin mampu mengurangi ekspresi sitokin dan sekresi. ${ }^{55}$ Flavonoid adalah suatu kelompok fenol terbesar ditemukan di alam yang mempunyai 15 atom karbon, atom karbon ini membentuk dua cincin benzene dan satu rantai propana dengan susunan $\mathrm{C}_{6} \mathrm{C}_{3} \mathrm{C}_{6}$ menghasilkan tiga struktur yaitu flavonoid (1,3-diaril propana), isoflavonoid (1,2-diaril propana) dan neoflavonoid (1,1-diarilpropana). ${ }^{59}$ Kandungan kimia daun Basella rubra Linn mengandung senyawa flavonoid. ${ }^{60}$ Menurut ilmu kemotaksonomi, hubungan kekerabatan yang dekat antara tanaman binahong dengan tanaman Basella rubra Linn yang berfamili Basellaceae memungkinkan memiliki kandungan kimia yang sama. Jenis senyawa flavonoid yang sudah ditemukan dalam daun Basella rubra Linn yaitu kaemferol ${ }^{61}$ dan apigenin. ${ }^{62}$ Dalam penelitian sebelumnya daun binahong diduga mengandung flavonoidjenis 4',6,7 Trihidroksi Auron dan 8glukopiranosil-4',5,7 Trihidroksiflavon. ${ }^{63,64}$

\section{Asam Sitrat}

Asam sitrat merupkan suatu derivat dari asam karboksilat (RCOOH), senyawa ini banyak dimanfaatkan di dalam berbagai aspek kehidupan. Pada dunia medis, kegunaan kelompok-kelompok senyawa asam berperan dalam proses penyembuhan luka, yakni dalam mencegah proses infeksi dari bakteri. Telah banyak penelitian yang melaporkan peranan dari asam sitrat dalam proses penyembuhan luka. Mahindiru et.al di tahun 2017 melaporkan secara statistika kegunaan asam sitrat dapat mempercepat penyembuhan luka, luas dari luka yang di treatment menggunakan asam sitrat 
memiliki luas area luka yang jauh lebih kecil daripada area luka tanpa treatment asam sitrat. Konsentrasi asam sitrat yang digunakan yakni sekitar 3\%. Bedasarkan data tersebut kegunaan asam sitrat diyakini efektif dalam proses
Mekanisme kerja asam sitrat dalam penyembuhan luka yakni melalui proses penurunan $\mathrm{pH}$ sari area luka, kemudian menghambat kerja dari bakteri, meningkatkan nilai konsentrasi oksigen dan mempercepat migrasi serta proliferasi fibroblast. ${ }^{65}$ penyembuhan luka pada segala jenis luka terbuka.

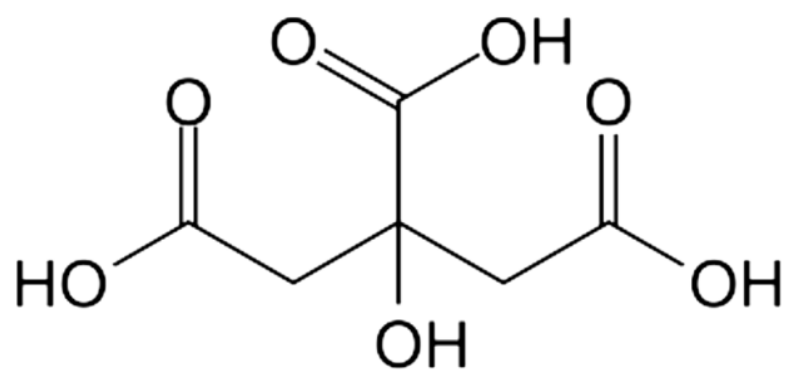

Gambar 8. Struktur Asam Sitrat

Pengaplikasian lain derivat dari senyawa asam sitrat yang ditemui dalam dunia medis adalah penggunaan senyawa sildenafil sitrat dalam penyembuhan luka diabetes. Mahre et.al (2017) melaporkan bahwa derivat dari senyawa sitrat ini dapat menurunkan kadar glukosa pada darah dan meningkatkan kadar sel darah merah yang di uji coba kan pada tikus penderita diabetes. ${ }^{66}$

\section{KESIMPULAN}

Berdasarkan studi literatur yang telah dilakukan pada hasil identifikasi senyawa aktif pada ekstrak daun binahong dan lainnya. Ditemukan keterkaitan bahwa senyawa aktif seperti alkaloid, flavonoid, terpenoid, dan saponin merupakan kelompok senyawa yang berpotensi untuk diaplikasikan dalam proses fabrikasi obat penyembuh luka berbahan dasar tumbuhan alam yakni daun Binahong. Faktor penentu yang menjadi dasar konsep isolasi senyawa tersebut adalah teknik ekstraksi yang digunakan. Teknik

padat cair dinilai efektif digunakan untuk menghindari dekomposisi atau penguraian senyawa, pemilihan pelarut yang cocok untuk esktraksi akan menghasilkan perbedaan nilai distribusi suatu senyawa kimia aktif pada larutan. Kloroform adalah senyawa kimia yang cenderung non-polar yang memiliki sifat dapat melarutkan komponen senyawa non-polar yang diduga memiliki aktivitas agen penyembuh luka alami. Hasil isolasi senyawa yang diperoleh perlu dikarakterisasi menggunakan teknik yang paling sederhana seperti TLC, identifikasi gugus fungsi menggunakan FTIR, identifikasi komposisi komponen menggunakan GC-MS, dan identifikasi struktur menggunakan NMR. Senyawa yang telah diidentifikasi dan ditentukan strukturnya kemudian dapat diuji coba aktivitasnya sebagai agen penyembuh luka. 


\section{DAFTAR PUSTAKA}

1. Kusumanti, E. \& Sugiharto, S. Effect of dietary supplementation of binahong leaf meal, betel nut meal or their combination on serum albumin and globulin, fecal endoparasites and bacterial counts in milk of Saanen goats suffering from subclinical mastitis. Agric. Nat. Resour. 51, 415-419 (2017).

2. Istyastono, E. \& Yuliani, S. H. Scarless wound healing gel with binahong (Anredera cordifolia (Ten) Steenis) leaves extract and celecoxib as the active ingredients. in Proceedings of the 1st International Conference on Science and Technology 2015 (ICST-2015) vol. 1755160001 (2016).

3. Gizaw, M. et al. Electrospun Fibers as a Dressing Material for Drug and Biological Agent Delivery in Wound Healing Applications. Bioengineering vol. 5 (2018).

4. Nasir, A., Sign, W. \& Test, R. The Influence of Binahong Leaves (Anredera Cordifolia) on Healing of Flour Albuson Female Students of Class XI SMAN 1 Pacitan Lamongan District. J. Vocat. Nurs. 1, 80-85 (2020).

5. Gonzalez, A. C. de O., Costa, T. F., Andrade, Z. de A. \& Medrado, A. R. A. P. Wound healing - A literature review. An. Bras. Dermatol. 91, 614-620 (2016).

6. Kintoko, K. et al. Effect of Diabetes Condition on Topical Treatment of
Binahong Leaf Fraction in Wound Healing Process. Maj. Obat Tradis. 22, 103 (2017).

7. Hasiib, E., Riyanti, R. \& Hartono, M. Pengaruh Pemberian Ekstrak Daun Binahong (Anredera Cordifolia (Ten.) Steenis) Dalam Air Minum Terhadap Performa Broiler. J. Ilm. Peternak. Terpadu 3, 233359 (2015).

8. Dong, S. et al. Antibacterial activity and mechanism of action saponins from Chenopodium quinoa Willd. husks against foodborne pathogenic bacteria. Ind. Crops Prod. 149, 112350 (2020).

9. Mahibalan, S., Stephen, M., Nethran, R. T., Khan, R. \& Begum, S. Dermal wound healing potency of single alkaloid (betaine) versus standardized crude alkaloid enrichedointment of Evolvulus alsinoides. Pharm. Biol. 54, 2851-2856 (2016).

10. Porras-Reyes, B. H., Lewis, W. H., Roman, J., Simchowitz, L. \& Mustoe, T. A. Enhancement of wound healing by the alkaloid taspine defining mechanism of action. Proc. Soc. Exp. Biol. Med. Soc. Exp. Biol. Med. (New York, N.Y.) 203, 18-25 (1993).

11. Moores, J. Vitamin C: a wound healing perspective. Br. J. Community Nurs. Suppl, S6, S8-11 (2013).

12. Bikker, A., Wielders, J., van Loo, R. \& Loubert, M. Ascorbic acid deficiency impairs 
wound healing in surgical patients: Four case reports. Int. J. Surg. Open 2, 15-18 (2016).

13. Nagoba, B. et al. Treatment of skin and soft tissue infections caused by Pseudomonas aeruginosa-A review of our experiences with citric acid over the past 20 years. Wound Med. 19, 5-9 (2017).

14. Nagoba, B. S., Aghav, V. V, Wadher, B. J., Rao, A. \& Selkar, S. P. The use of citric Acid for the treatment of chronic non-healing sinus. Iran. J. Med. Sci. 36, 63-64 (2011).

15. Andrade-Eiroa, A., Canle, M., LeroyCancellieri, V. \& Cerdà, V. Solid-phase extraction of organic compounds: A critical review. part ii. TrAC Trends Anal. Chem. 80, 655-667 (2016).

16. Zhang, Q.-W., Lin, L.-G. \& Ye, W.-C. Techniques for extraction and isolation of natural products: a comprehensive review. Chin. Med. 13, 20 (2018).

17. Schoemig, V., Isik, E., Martin, L. \& Berensmeier, S. Solid liquid liquid extraction of porcine gastric mucins from homogenized animal material. RSC Adv. 7, 39708-39717 (2017).

18. Vasilescu, M. N. \& Medvedovici, A. V. Herbicides. in Encyclopedia of Analytical Science (Second Edition) (eds. Worsfold, P., Townshend, A. \& Poole, C. B. T.-E. of A. S. (Second E.) 243-260 (Elsevier, 2005). doi:https://doi.org/10.1016/B0-12-3693977/00256-9.
19. Berk, Z. Chapter 11 - Extraction. in Food Science and Technology (ed. Berk, Z. B. T.F. P. E. and T.) 259-277 (Academic Press, 2009). doi:https://doi.org/10.1016/B978-012-373660-4.00011-9.

20. Hage, D. S. 1 - Chromatography. in Principles and Applications of Clinical Mass Spectrometry (eds. Rifai, N., Horvath, A. R. \& Wittwer, C. T. B. T.-P. and A. of C. M. S.) 1-32 (Elsevier, 2018). doi:https://doi.org/10.1016/B978-0-12816063-3.00001-3.

21. Kagarise, B. A. 3 - Peptide Mapping at the Nanomole Level. in (eds. LEFKOVITS, I. \& PERNIS, B. B. T.-I. M.) 69-80 (Academic Press, 1979). doi:https://doi.org/10.1016/B978-0-12442750-1.50008-5.

22. Ikan, R. \& Crammer, B. Organic Chemistry, Compound Detection. in Encyclopedia of Physical Science and Technology (Third Edition) (ed. Meyers, R. A. B. T.-E. of P. S. and T. (Third E.) 459-496 (Academic Press, 2003). doi:https://doi.org/10.1016/B0-12227410-5/00541-X.

23. Santiago, M. \& Strobel, S. Chapter TwentyFour - Thin Layer Chromatography. in Laboratory Methods in Enzymology: Cell, Lipid and Carbohydrate (ed. Lorsch, J. B. T.M. in E.) vol. 533 303-324 (Academic Press, 2013). 
24. Hostettmann, K. \& Marston, A. Saponins. Encyclopedia of Analytical Science (Second Edition) 205-209

doi:https:/ /doi.org/10.1016/B0-12-3693977/00548-3.

25. Ismail, A. A., van de Voort, F. R. \& Sedman, J. Chapter 4 Fourier Transform Infrared pectroscopy: Principles and Applications. in Instrumental Methods in Food Analysis (eds. Paré,J. R. J. \& Bélanger, J. M. R. B. T.-T. and I. in A. C.) vol. 18 93-139 (Elsevier, 1997).

26. Markovich, R. J. \& Pidgeon, C. Introduction to Fourier Transform Infrared Spectroscopy and Applications in the Pharmaceutical Sciences. Pharm. Res. 8, 663-675 (1991).

27. Mohamed, M. A., Jaafar, J., Ismail, A. F., Othman, M. H. D. \& Rahman, M. A. Chapter 1 - Fourier Transform Infrared (FTIR) Spectroscopy. in Membrane Characterization (eds. Hilal, N., Ismail, A. F., Matsuura, T. \& Oatley-Radcliffe, D. B. T.-M. C.) 3-29 (Elsevier, 2017). doi:https://doi.org/10.1016/B978-0-44463776-5.00001-2.

28. Pavia, D L., Lampman, G M., Kriz, G. S. Introduction to Spectroscopy. (1995). doi:10.1201/9781420050691.pt1.

29. Deda, O., Gika, H., Raikos, N. \& Theodoridis, G. Chapter 4 - GC-MS-Based Metabolic Phenotyping. in The Handbook of Metabolic Phenotyping (eds. Lindon, J. C., Nicholson, J. K. \& Holmes, E. B. T.-T. H. of
M. P.) 137-169 (Elsevier, 2019). doi:https://doi.org/10.1016/B978-0-12812293-8.00004-9.

30. Sparkman, O. D., Penton, Z. E. \& Kitson, F. G. Chapter 1 - Introduction and History. in Gas Chromatography and Mass Spectrometry (Second edition) (eds. Sparkman, O. D., Penton, Z. E. \& Kitson, F. G. B. T.-G. C. and M. S. (Second E.) 2-13 (Academic Press, 2011). doi:https://doi.org/10.1016/B978-0-12373628-4.00001-0.

31. Gilbert, J. R. et al. Chapter 17 - Industrial Applications of High-Resolution GC/MS. in Advanced Techniques in Gas Chromatography-Mass Spectrometry (GCMS-MS and GC-TOF-MS) for Environmental Chemistry (eds. Ferrer, I. \& Thurman, E. M. B. T.-C. A. C.) vol. 61403 429 (Elsevier, 2013).

32. Beira, M. et al. 1H NMR Relaxometry and Diffusometry Study of Magnetic and Nonmagnetic Ionic Liquid-Based Solutions: Cosolvent and Temperature Effects. J. Phys. Chem. B 121, 11472-11484 (2017).

33. Pauli, G. F., Jaki, B. U. \& Lankin, D. C. Quantitative 1H NMR: Development and Potential of a Method for Natural Products Analysis. J. Nat. Prod. 68, 133-149 (2005).

34. Dais, P. \& Spyros, A. Chapter 4 - Nuclear Magnetic Resonance. in Chemical Analysis of Food: Techniques and Applications (ed. 
Picó, Y. B. T.-C. A. of F. T. and A.) 91-115 (Academic Press, 2012). doi:https://doi.org/10.1016/B978-0-12384862-8.00004-2.

35. Riegel, S. D. \& Leskowitz, G. M. Benchtop NMR spectrometers in academic teaching. TrAC Trends Anal. Chem. 83, 27-38 (2016).

36. Hollmann, M. W., Durieux, M. E. \& Fisher, D. M. Local Anesthetics and the Inflammatory Response: A New Therapeutic Indication? Anesthesiology 93, 858-875 (2000).

37. Cañedo-Dorantes, L. \& Cañedo-Ayala, M. Skin acute wound healing: A comprehensive review. Int. J. Inflam. 2019, (2019).

38. Boyko, T. V, Longaker, M. T. \& Yang, G. P. Review of the Current Management of Pressure Ulcers. Adv. wound care 7, 57-67 (2018).

39. Tandara, A. A. \& Mustoe, T. A. Oxygen in wound healing--more than a nutrient. World J. Surg. 28, 294-300 (2004).

40. Nuutila, K., Katayama, S., Vuola, J. \& Kankuri, E. Human Wound-Healing Research: Issues and Perspectives for Studies Using Wide-Scale Analytic Platforms. Adv. wound care 3, 264-271 (2014).

41. Lordan, R., Tsoupras, A. \& Zabetakis, I. Chapter 2 - Inflammation. in The Impact of Nutrition and Statins on Cardiovascular Diseases (eds. Zabetakis, I., Lordan, R. \& Tsoupras, A. B. T.-T. I. of N. and S. on C. D.)
23-51 (Academic Press, 2019). doi:https://doi.org/10.1016/B978-0-12813792-5.00002-1.

42. García-Pérez, P., Barreal, M. E., Rojo-De Dios, L., Cameselle-Teijeiro, J. F. \& Gallego, P. P. Chapter 2 - Bioactive Natural Products From the Genus Kalanchoe as Cancer Chemopreventive Agents: A Review. Stud. Nat. Prod. Chem. 61, 49-84 (2019).

43. Kumar, V., Abbas, A., Fausto, N. \& Aster, J. Pathologic Basis of Disease, Professional Edition. (Elsevier, 2009).

44. Eming, S. A., Martin, P. \& Tomic-Canic, M. Wound repair and regeneration: mechanisms, signaling, and translation. Sci. Transl. Med. 6, 265sr6-265sr6 (2014).

45. Mulyata, S. Analisis imunohistokimia TGF $\beta$ indikasi hambatan kesembuhan luka operasi episiotomi pada tikus Sprague Dawley. Indones. Symp. Obstet. Anesth. (2002).

46. Li, W. et al. Wound-healing perspectives. Dermatol. Clin. 23, 181-192 (2005).

47. Perencanaan Buku Media Informasi tentang Manfaat Tanaman Binahong untuk Terapi Herbal pada Penyembuh Luka. (Universitas Komputer Indonesia, 2010).

48. Manoi, F. \& Balittro. Binahong (Anredera cordifolia) sebagai obat. J. War. Penelit. dan Pengemb. Tanam. Ind. 15, 3-4 (2009).

49. Pengaruh Konsentrasi Ekstrak Daun Binahong (Anredera cordifolia (Ten.) Steenis) 
terhadap Jumlah Pembuluh Darah pada Penyembuhan Luka Gingiva Tikus Putih (Rattus norvegicus). (Universitas Gajah Mada, 2013).

50. Hartono, E., Sugeng, S. \& Puradisastra, S. Efek Ekstrak Etanol Daun Binahong (Anredera cordifolia (Ten.) Steenis) dalam Mempercepat Durasi Penyembuhan Luka Sayat pada Mencit Swiss Webster Jantan. (Universitas Kristen Maranatha, 2011).

51. Paju, N., Yamlean, P. V. \& Kojong, N. Uji Efektivitas Salep Ekstrak Daun Binahong (Anredera Cordifolia (Ten.) Steenis) pada Kelinci Oryctolagus cuniculus) yang Terinfeksi Bakteri Staphylococcus aureus. J. Ilm. Farm. UNSRAT 2, 2302 - 2493 (2013).

52. Darsana, I. G., Besung, I. N. \& Mahatmi, H. Potensi daun binahong (Anredera cordifolia (Tenore) Steenis) dalam menghambat pertumbuhan bakteri Escherichia coli secara in vitro. Indones. Med. Veterinus 1, 337 351 (2012)

53. Robbins, S. \& Kumar, V. Buku Ajar Patologi. (EGC, 2007).

54. Guyton \& Hall. Buku Ajar Fisiologi Kedokteran Ed.9. (EGC, 1997).

55. Nijveldt, R. J. et al. Flavonoids: a review of probable mechanisms of action and potential applications. Am. J. Clin. Nutr. 74, 418-425 (2001).

56. Selawa, W., Runtuwene, M. R. \& Citraningtyas, G. Kandungan Flavonoid dan
Kapasitas Antioksidan Total Ekstrak Etanol Daun Binahong (Anredera cordifolia (Ten) Steenis). J. Ilm. Farasi UNSRAT. Manad. 1822 (2013).

57. Hasanoglu, A. et al. Efficacy of Micronized Flavonoid Fraction in Healing of Clean and Infected Wounds. Int. J. Angiol. Off. Publ. Int. Coll. Angiol. Inc 10, 41-44 (2001).

58. Kumar, S. \& Pandey, A. K. Chemistry and Biological Activities of Flavonoids: An Overview. Sci. World J. 2013, 162750 (2013).

59. Harbone, J. Penentuan cara modern menganalisis tumbuhan. (Institut Teknologi Bandung, 1987).

60. Nirmala, W., Budiyanto, E., Ardi, Y.W., Hendry, S. Pemanfaatan Ekstrak Daun Kemangi (Ocinum canum) Sebagai Permen Herbal Pencegah Bau Mulut. (UNY, 2009).

61. Yang, R.-Y., Lin, S. \& Kuo, G. Content and distribution of flavonoids among 91 edible plant species. Asia Pac. J. Clin. Nutr. 17 Suppl 1, 275-279 (2008).

62. Bhagwat, S. \& Haytowitz, D. B. USDA Database for the Flavonoid Content of Selected Foods. (2015).

63. Susmayanti, W. Isolasi, Identifikasi dan Uji Toksisitas Senyawa FlavonoidDari Ekstrak Daun Binahong (Anredera cordiforlia (Tenns) Stennis). (Universitas Diponegoro, 2011). 
64. Djamil, R., Wahyudi, P., Wahono, S. \& Hanafi. Antioxidant Activity of Flavonoid from Anredera Cordifolia (Ten) steenis Leaves. J. Pharm. (2012).

65. Mahindru, S. \& Resident, J. Evaluation of effect of topical application of 3\% citric acid on wound healing. Int. J. Curr. Res. Med. Sci. 3, 30-38 (2017).

66. Mahre, M. et al. Haematological changes and wound healing effects of sildenafil citrate in diabetic albino rats. Sokoto J. Vet. Sci. 15, (2017). 